\title{
A meta-analysis of particle water uptake reconciliation studies
}

\author{
J. D. Whitehead ${ }^{1}$, M. Irwin ${ }^{1, *}$, J. D. Allan ${ }^{1}$, N. Good ${ }^{1, * *}$, and G. McFiggans ${ }^{1}$ \\ ${ }^{1}$ Centre for Atmospheric Science, SEAES, University of Manchester, Oxford Road, Manchester, M13 9PL, UK \\ *now at: Cambustion Ltd., Cambridge, CB1 8DH, UK \\ *** now at: Department of Environmental \& Radiological Health Sciences, Colorado State University, Fort Collins, \\ Colorado, USA
}

Correspondence to: G. McFiggans (g.mcfiggans@manchester.ac.uk)

Received: 25 March 2014 - Published in Atmos. Chem. Phys. Discuss.: 15 April 2014

Revised: 27 August 2014 - Accepted: 7 October 2014 - Published: 11 November 2014

\begin{abstract}
Water uptake by aerosol particles controls their ability to form cloud droplets, and reconciliation between different techniques for examining cloud condensation nuclei $(\mathrm{CCN})$ properties is important to our understanding of these processes and our ability to measure and predict them. Reconciliation between measurements of sub-saturated and supersaturated aerosol particle water uptake was attempted at a wide range of locations between 2007 and 2013. The agreement in derived number of $\mathrm{CCN}\left(N_{\mathrm{CCN}}\right)$ or particle hygroscopicity was mixed across the projects, with some data sets showing poor agreement across all supersaturations and others agreeing within errors for at least some of the supersaturation range. The degree of reconciliation did not seem to depend on the environment in which the measurements were taken. The discrepancies can only be attributable to differences in the chemical behaviour of aerosols and gases in each instrument, leading to under- or overestimated growth factors and/or CCN counts, though poorer reconciliation at lower supersaturations can be attributed to uncertainties in the size distribution at the threshold diameter found at these supersaturations. From a single instrument, the variability in $N_{\mathrm{CCN}}$ calculated using particle hygroscopicity or size distribution averaged across a project demonstrates a greater sensitivity to variation in the size distribution than chemical composition in most of the experiments. However, the discrepancies between instruments indicate a strong requirement for reliable quantification of $\mathrm{CCN}$ in line with an improved understanding of the physical processes involved in their measurement. Without understanding the reason for discrepancies in the measurements, it is questionable whether quantification of $\mathrm{CCN}$ behaviour is meaningful.
\end{abstract}

\section{Introduction}

Changes to the number of cloud condensation nuclei (CCN) will impact on cloud microphysical properties, with an increase in CCN resulting in more and smaller cloud droplets and in brighter clouds (Twomey, 1977) with longer lifetimes, higher liquid water content and increased cloud thickness (Stevens and Feingold, 2009). The net effect of these aerosol-cloud interactions is to cool the climate system, however significant uncertainties remain in predicting the magnitude of this impact (Boucher et al., 2013). A better understanding of these interactions is needed to improve climate predictions.

The ability of aerosol particles to act as $\mathrm{CCN}$ depends upon their size and chemical composition. A number of regional and global models have been developed over recent years to predict $\mathrm{CCN}$ number concentrations based on these parameters (e.g. Spracklen et al., 2008; Kumar et al., 2009). In order to verify and improve these models, measurements of $\mathrm{CCN}$ properties from a wide range of locations around the world are needed.

$\mathrm{CCN}$ properties of aerosols can be measured in the subsaturated regime with a Hygroscopicity Tandem Differential Mobility Analyser (HTDMA; for a review, see Swietlicki et al., 2008) and in the supersaturated regime with a cloud condensation nuclei counter $(\mathrm{CCNc}$; Roberts and Nenes, 2005). Reconciliation studies between these two measurement techniques allows us to test our understanding of aerosol water uptake processes, and to investigate the suitability of applying simplifying assumptions to models.

Extrapolation between the sub- and supersaturation regime can be approximated through Köhler theory with 
hygroscopicity described by a single parameter. Several such parameters have been proposed (for a review, see Rissler et al., 2010), such as that of Petters and Kreidenweis (2007). Denoted $\kappa$, this has been widely used in recent years (e.g. Andreae and Rosenfeld, 2008; Kammermann et al., 2010; Irwin et al., 2010, 2011), particularly in reconciling sub-saturated particle hygroscopicity with CCN measurements. Several hygroscopicity-CCN reconciliation studies have been published over the past decade or so (e.g. Zhou et al., 2002; Rissler et al., 2004; Jurányi et al., 2010; Kammermann et al., 2010; Irwin et al., 2010, 2011; Fors et al., 2011); however all these studies concentrated on measurements at a single site, making it impossible to generalise the conclusions. Here we present, for the first time, a meta-analysis of reconciliation studies by our group at a large number of different locations including marine, tropical, background continental and urban environments. Such a comprehensive compilation of reconciliation studies allows us to explore instrumental discrepancies and whether reconciliation is affected by the environment in which the measurements were taken.

\section{Measurements and methods}

Figure 1 shows all the experiments from 2006 to 2013 at which measurements were made with the HTDMA and $\mathrm{CCNc}$ instruments described below. The measurements that are included in this study are labelled in bold in the figure text. These include a total of eight locations, at two of which (Mace Head and London), separate summer and winter measurement campaigns were conducted. In each campaign, the measurements were conducted over three to six weeks at a time. The measurements covered a range of different ambient environments including marine (Discovery cruise, Mace Head, Weybourne), tropical (Borneo, Amazonia), continental background (Hornisgrinde, Chilbolton) and urban (London). These data sets were selected out of all those in Fig. 1 for the quality of the data and suitability of measurement configuration for reconciliation study. The HTDMA and/or CCNc measurement data collected in the other experiments shown in Fig. 1 were less suited to hygroscopicity-CCN reconciliation.

For each experiment, $\mathrm{CCN}$ activity was measured as a function of supersaturation and particle dry size using a Droplet Measurement Technologies cloud condensation nuclei counter (CCNc; Roberts and Nenes, 2005). The calibration and operation of the $\mathrm{CCNc}$ is described fully by Good et al. (2010a, b) and Irwin et al. (2010, 2011), with mostly the same methods used in all projects. Briefly, a dried $(<20 \% \mathrm{RH}$, relative humidity) monodisperse aerosol sample was supplied by a differential mobility analyser (DMA) stepping discretely through a range of sizes (the exception being Chilbolton, where the sample was not dried). The sample was then split between the $\mathrm{CCNc}$ and a condensation particle counter (CPC; TSI model 3010). The ratio of the number of $\mathrm{CCN}\left(N_{\mathrm{CCN}}\right)$ to the total number concentration of aerosol particles $\left(N_{\mathrm{CN}}\right)$ is the fraction of particles activated $\left(F_{\mathrm{A}}\left(S, D_{0}\right)\right)$ at a given supersaturation, $S$, and dry diameter, $D_{0}$. The resulting activation spectra $\left(F_{\mathrm{A}}\left(S, D_{0}\right)\right.$ as a function of dry diameter, $D_{0}$ ) can be used to derive the diameter at which $50 \%$ of the particles activate $\left(D_{50}\right)$ by fitting a sigmoid curve function. The hygroscopicity parameter, $\kappa$, can then be derived using the $\kappa$-Köhler model, and will be denoted by $\kappa_{D_{50}}$.

Hygroscopic growth factor distributions were measured during each experiment using a Hygroscopicity Tandem Differential Mobility Analyser (HTDMA). Two different instruments were used: the first (HTDMA1), developed by $\mathrm{Cu}-$ bison et al. (2005), was used during the Discovery, Hornisgrinde, Borneo, and Amazonia experiments, while the second (HTDMA2), developed by Good (2009), was used in the remaining experiments. In all cases, calibrations were conducted as discussed by Good et al. (2010a), and the data were processed using the TDMAinv software described by Gysel et al. (2009). In the HTDMA, a dry aerosol sample is size-selected with the first DMA and then humidified to $90 \%$ RH (except at Hornisgrinde where $86 \%$ RH was used; Irwin et al., 2010). The second DMA is then used to measure the size distribution of the humidified aerosol, to give the distribution of Growth Factor (defined as the ratio of wet to dry aerosol diameter) as a function of $\mathrm{RH}$ and dry diameter $\left(\mathrm{GF}_{\mathrm{RH}, D_{0}}\right)$. For most of the studies, 5 to 7 dry sizes were scanned in this way, ranging from 24 to $300 \mathrm{~nm}$. Values of $\kappa$ can be calculated from the mean growth factor measurements as described by Eq. (1):

$S=\frac{\overline{\mathrm{GF}}^{3}-1}{{\overline{\mathrm{GF}^{3}}}^{3}-(1-\kappa)} \exp \left(\frac{4 \sigma_{\mathrm{w}} M_{\mathrm{w}}}{R T \rho_{\mathrm{w}} D_{0} \overline{\mathrm{GF}}}\right)$,

where $S$ is the supersaturation (RH $/ 100 \%$ ), $\overline{\mathrm{GF}}$ is the mean growth factor, $\kappa$ is the hygroscopicity parameter, $\sigma$ is the surface tension of water, $M_{\mathrm{w}}$ is the molar mass of water, $R$ is the universal gas constant, $T$ is the temperature, $\rho_{\mathrm{w}}$ is the density of water and $D_{0}$ is the dry diameter. The $\kappa$ derived from the growth factor data will be denoted by $\kappa_{\mathrm{GF}}$.

A number of approaches can be taken to calculate total $N_{\mathrm{CCN}}$ as a function of supersaturation. From the $\mathrm{CCNc}$ data, the simplest way is to integrate $N_{\mathrm{CCN}}\left(S, D_{0}\right)$ as a function of $D_{0}$ for each set supersaturation, $S_{\text {set }}$. Alternatively, the aerosol number size distribution (as measured by the CPC on the DMA) can be integrated from the largest size down to a threshold diameter (in this case, the $D_{50}$ derived from the activation spectra). For the HTDMA data, a threshold diameter can be derived from the calculated $\kappa_{\mathrm{GF}}$ values for a given supersaturation, and from this, $N_{\mathrm{CCN}}$ can be calculated as before. By using the $S_{\text {set }}$ from the CCNc in deriving $N_{\mathrm{CCN}}$ from the HTDMA, a direct comparison between the instruments can be made. In this study, $N_{\mathrm{CCN}}$ from the $\mathrm{CCNc}$ data is derived from the aerosol size distribution and $D_{50}$ and compared with $N_{\mathrm{CCN}}$ derived from the HTDMA data. $\kappa$ values 


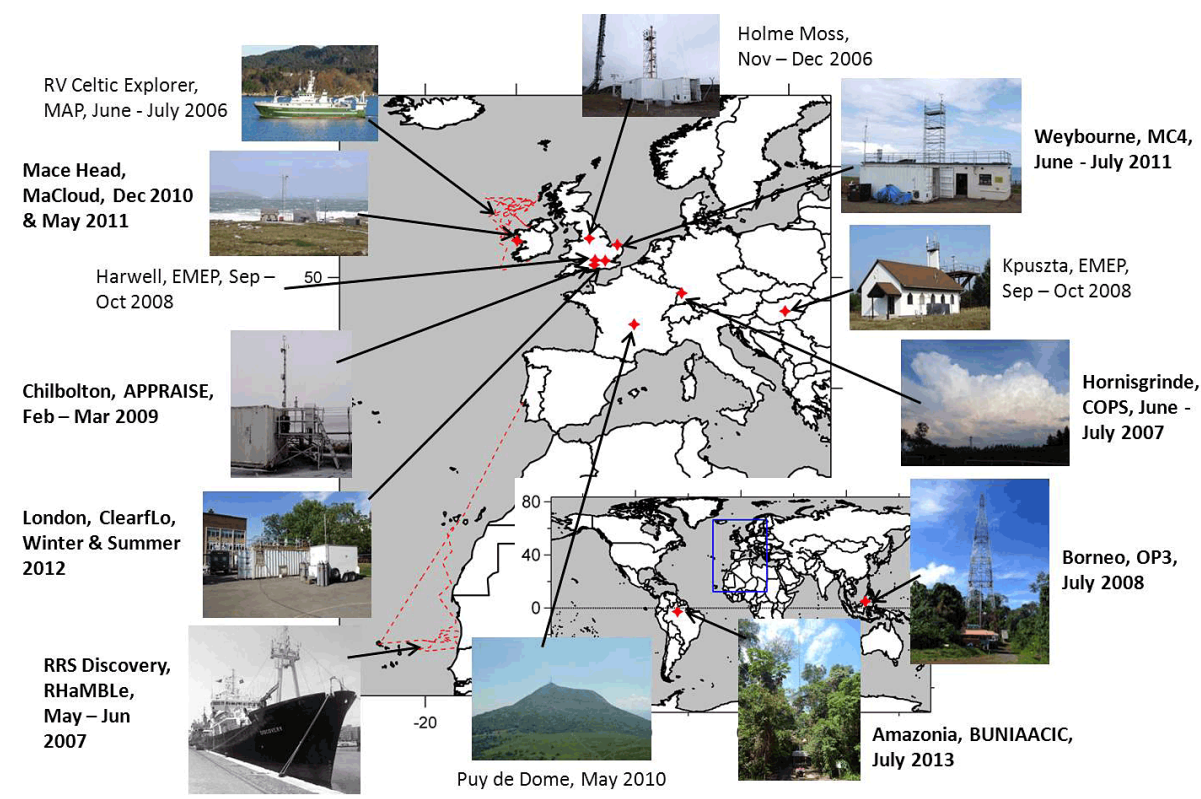

Figure 1. Map showing the locations of measurements. The labels name the locations, projects and dates of the experiments. The data sets used in this study are labelled in bold print.

are also compared between the instruments using the methods described above.

The calibration procedures employed in all experiments for both the CCNc and HTDMA are rigorous and described in detail by Good et al. (2010a). The DMA upstream of the $\mathrm{CCNc}$ and the first DMA in the HTDMA were calibrated using latex spheres. The HTDMA was operated for a few hours without humidification every week or two, to calibrate for any offset between the two DMAs, and to define the instrument's transfer function. Both the HTDMA and the CCNc were generally calibrated at the start and end of each experiment using nebulised ammonium sulfate. For the HTDMA, this calibration involved running a humidogram: i.e. measuring the GF at a range of RHs at a fixed dry diameter (typically $150 \mathrm{~nm}$ ), and comparing to theoretical GF (Topping et al., 2005). Corrections can then be made to the measured $\mathrm{RH}$ where necessary. The $\mathrm{CCNc}$ was calibrated by sampling nebulised and dried monodisperse ammonium sulfate from a DMA at 3-5 mobility diameters between 30 and $100 \mathrm{~nm}$. At each diameter the temperature gradient in the $\mathrm{CCNc}$ was stepped up and an activation curve $(\mathrm{CCN} / \mathrm{CN})$ was derived. The temperature gradient at which $50 \%$ of the particles were counted as $\mathrm{CCN}$ was assumed to correspond to the critical supersaturation. The temperature gradient to supersaturation relation was then derived by a linear fit to the theoretical (Topping et al., 2005) critical supersaturation at each diameter.

\section{Results and discussion}

The median and ranges of the aerosol size distributions for each campaign are shown in Fig. 2. In all cases, these were derived from the DMA and CPC attached to the CCNc. These show a wide variation in the aerosol size distributions between the different campaigns, and a similarly wide variation can be seen in the GF distributions from the HTDMA measurements, which are shown in the Supplement for each experiment, and are reported for $90 \% \mathrm{RH}$ at all locations (except Hornisgrinde, which is reported at $86 \% \mathrm{RH}$ ). The aerosol size distributions observed in London are similar to previous measurements (e.g. Van Dingenen et al., 2004; Rodriguez et al., 2007), while the GF distributions show an external mixture with hydrophobic $(\mathrm{GF} \approx 1)$ and hygroscopic modes $(\mathrm{GF}=1.5)$, similar to other urban measurements (Jurányi et al., 2013). At Mace Head, the winter measurements were dominated by "modified marine" air masses, while the summer experiment saw a largely "clean marine" fetch, and the measured size distributions were typical of these respective air masses (Dall'Osto et al., 2011). The modified marine GF distribution was dominated by a hydrophobic mode $(\mathrm{GF} \approx 1.1)$, while the clean marine had a strong sea salt mode $(\mathrm{GF} \approx 2.2)$. Both experiments exhibited a hygroscopic mode ( $\mathrm{GF}=1.5-1.7)$, which largely dominated in the summer campaign but showed significant variability along with the sea salt mode. Both the aerosol size distributions and the GF distributions measured in the Amazon were typical at that site in the dry season (Artaxo et al., 2013), but differed considerably from the other tropical measurements at the Borneo site, which, by contrast, was strongly influenced 


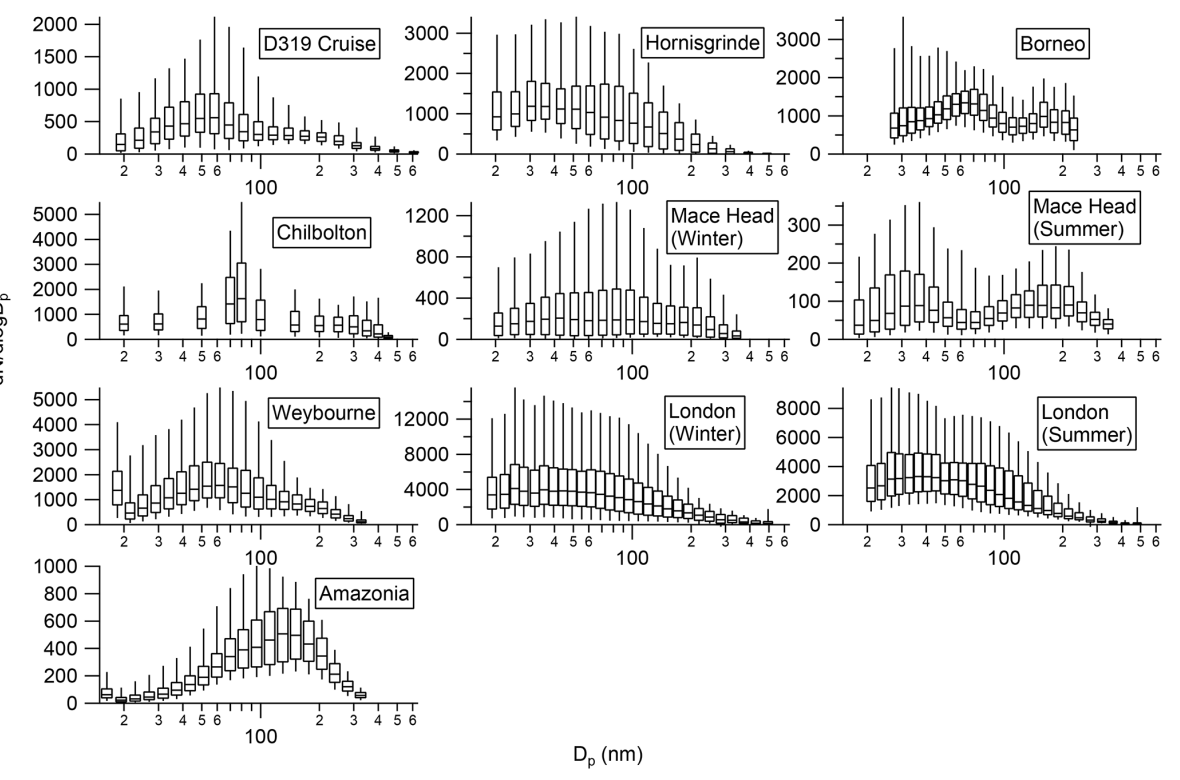

Figure 2. Size distribution box-and-whisker plots showing the median, interquartile ranges and 5th and 95th percentile size distributions for each measurement campaign.

by marine air masses (Irwin et al., 2011). In the Amazon, the GF distributions show a persistent, internally mixed aerosol with GF 1.2-1.3, while in Borneo, the dominant mode varied between GF 1.4-1.6 (depending on dry size) with an occasional hydrophobic mode. From its location, Chilbolton is regarded as a rural background site, and further analysis of other measurements taken during this campaign (unpublished data) suggests the aerosol is largely representative of regional properties, with only a small influence from local sources. The GF distributions show a persistent external mixture with modes around 1.1 and 1.5. The Discovery cruise took place off the coast of West Africa, and over the course of the campaign, three distinct air masses were seen: African, Continental (from Southern Europe) and Marine. These are not separated out for the purposes of this study, and the size distribution in Fig. 2 represents the whole data set. Growth factors were mostly around 1.7, and showed a largely internal mixture for most of the experiment, except for a sporadic sea salt mode at the larger sizes. A more in-depth examination of this is provided by Good et al. (2010b). Hornisgrinde is a mountaintop site, which was frequently in cloud during measurements (Irwin et al., 2010), and is described as "continental background". The GF distribution is more variable with time and dry size that at some of the other experiments, ranging 1.1-1.4 (at $86 \% \mathrm{RH}$ ). A bimodal GF distribution can be seen sometimes at the larger dry sizes. Finally Weybourne, while being coastal, can experience a variety of different air masses, and did so during the experiment (Liu et al., 2013), and frequently sees aged polluted plumes from the UK and mainland Europe. The GF distributions show a dominant hygroscopic mode (which seems to vary diurnally between 1.4 and 1.7), accompanied by a weaker hydrophobic mode. As with the other campaigns, the Weybourne data set was considered as a whole for the purpose of this study. The compilation of all these data sets therefore provides a wide range of aerosol populations, typically present in the atmosphere at different locations. From this, it should be possible to probe whether this variation has any influence on the reconciliation.

For each measurement campaign, the mean values of $N_{\mathrm{CCN}}$ and $\kappa$ derived from $D_{50}$ and GF were found for each $S_{\text {set }}$, and the ratios of these means are plotted in Fig. 3. The error bars represent the standard deviation of these ratios, and hence show the variation throughout a given experiment. In some campaigns, where the HTDMA calibrations drifted between the start and end of the experiment, both were applied and the spread is illustrated in Fig. 3 as shaded areas. The graphs show that the level of reconciliation varied greatly between the different experiments, generally varying with supersaturation. Poorest agreement between the HTDMA and $\mathrm{CCNc}$ across the range of supersaturations was found in the measurements from Hornisgrinde, Borneo, Chilbolton and the Discovery cruise. The other experiments largely showed agreement within the error bars for at least some of the supersaturation range. In general, there seems to be a tendency for the HTDMA measurements to underestimate hygroscopicity compared to the $\mathrm{CCNc}$, especially at lower supersaturations, resulting in a ratio greater than one. The only exception to this is the Borneo experiment, though it is not clear why this is the case.

It is also not clear why the results for the Hornisgrinde and Discovery cruise data sets stand out in the reconciliation in Fig. 3. Possible reasons for discrepancies between $\mathrm{CCNc}$ 

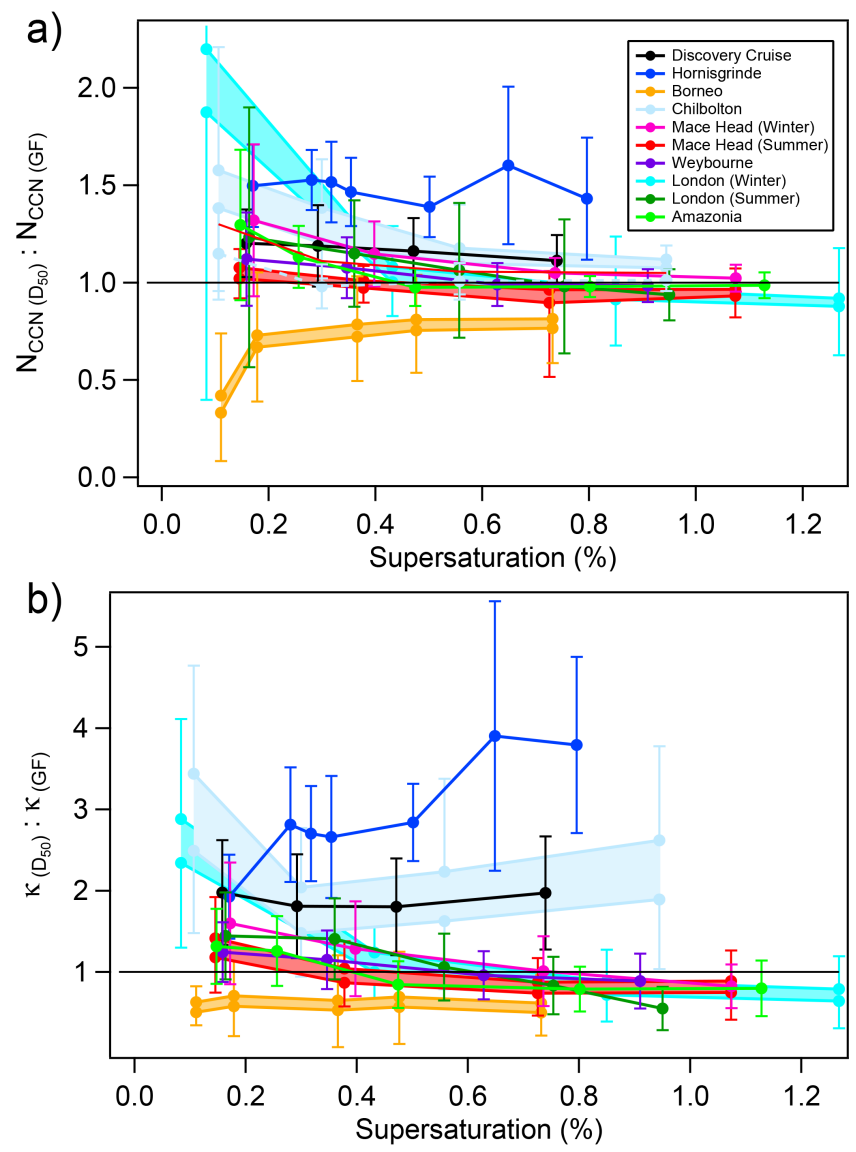

Figure 3. Ratios of mean $D_{50}$ and GF derived (a) $N_{\mathrm{CCN}}$ and (b) $\kappa$ values as a function of $S_{\text {set }}$ for each measurement campaign. Error bars represent one standard deviation. The shaded areas represent the spread of values due to differing HTDMA calibrations.

and HTDMA derived $\kappa$ and $N_{\mathrm{CCN}}$ for the Discovery, Hornisgrinde and Borneo data sets have been discussed at length by Good et al. (2010b) and Irwin et al. (2010, 2011), respectively, and they are likely to apply in varying degrees to the other data sets. The discrepancies are described as being due either to instrumental differences or assumptions made in the model. Previously, discrepancies between measured and modelled CCN behaviour have been attributed variously to particle surface tension at the point of activation, changes in the kinetics of uptake in the instruments, or external mixing.

When using the $\kappa$-Köhler model, the surface tension is often assumed to be that of pure water, $\sigma=0.072 \mathrm{~J} \mathrm{~m}^{-2}$ (Petters and Kreidenweis, 2007; Rissler et al., 2010). In reality, surface active compounds may concentrate at the water-air interface of a deliquesced particle, suppressing surface tension and affecting the $\mathrm{CCN}$ activity of the particle. A number of studies have explored the effect of this assumption on reconciliation, and have found either that reducing surface tension in the calculations would not improve closure (Jurányi et al., 2010), or that unrealistic values of surface tension would be required to account for discrepancies (Irwin et al.,
2010; Good et al., 2010b). Moreover, more recent work has demonstrated that bulk-to-surface partitioning offsets most of the influence of any surface tension reduction $(\mathrm{Li}$ et al., 1998; Sorjamaa et al., 2004; Kokkola et al., 2006; McFiggans et al., 2006; Topping et al., 2007; Topping, 2010; Frosch et al., 2010, 2011; Romakkaniemi et al., 2011; Prisle et al., 2012).

The $\kappa$-Köhler model also does not account for changes in solution non-ideality as a function of saturation ratio. To date, it has been very difficult to probe how $\kappa$ varies as RH increases towards $100 \%$ due to the uncertainties in HTDMA instruments at high RH (Good et al., 2010b; Duplissy et al., 2009). Recent developments (Suda and Petters, 2013) should make this possible. The presence of slightly soluble compounds can influence the reconciliation, by only contributing measurably to water uptake in supersaturated conditions. This would result in an underestimate in $N_{\mathrm{CCN}}$ from the HTDMA measurements (Dusek et al., 2011). Particle nonsphericity, and the effect this has on their classification in DMAs, can also have the effect of suppressing the calculated $\kappa$ from both GF and CCN measurements. This is because of the difference between a non-spherical particle's mobility diameter and its volume equivalent diameter. In sensitivity studies, Dusek et al. (2011) found that the $\kappa$ suppression was greater in GF calculations than from measured $\mathrm{CCN}$ data, resulting again in an underestimate of hygroscopicity from the HTDMA measurements compared to the $\mathrm{CCNc}$ measurements. These effects would result in the hygroscopicity being underestimated by the GF calculations compared to the CCNc derived values (Dusek et al., 2011), and therefore may be partly the reason why there is a tendency towards a greater than one ratio, as seen in Fig. 3.

Instrumental differences mainly relate to the chemical behaviour of aerosols and gases in the respective instruments. Growth factor may be underestimated in the HTDMA if the residence time following humidification is too short to reach equilibrium before sizing in the second DMA (Duplissy et al., 2009), leading to an underestimate of hygroscopicity. In addition, volatile and semi-volatile compounds can evaporate during the drying process. While the HTDMA and $\mathrm{CCNc}$ use the same dryer in all these measurements, the subsequent behaviour of the volatilised gases in the different conditions of each instrument can lead to further discrepancies (Irwin et al., 2010). For example, the saturation column of the $\mathrm{CCNc}$ can act as a mist chamber, where droplets take on soluble material from the gas phase, potentially increasing the $N_{\mathrm{CCN}}$ count. Indeed, the possible influences of semivolatile components on droplet activation and on reconciliation between sub- and supersaturated measurements has been discussed by Topping and McFiggans (2012) and the impacts of semi-volatile co-condensation expanded by Topping et al. (2013).

One possible reason for the higher discrepancy in the Chilbolton reconciliation is the fact that the aerosol sample was not dried before entering the instruments (Chilbolton 


\section{8}

was the only exception). The RH was often above $50 \%$ and as much as $70 \%$, and the DMAs were therefore not selecting dry sizes. To test the effect of this, the values for the dry sizes were reduced (and $\overline{\mathrm{GF}}$ increased) by a factor of 1.1 , to simulate dry aerosol sizes, and the analysis repeated to get the ratios. Figure S1 in the Supplement shows that this results in a substantial improvement in the reconciliation, especially for the $N_{\mathrm{CCN}}$ ratios. It should be stated here that while the factor of 1.1 represents a realistic value at the RH measured in the aerosol sample, it cannot be verified, nor does it reflect the variability in inlet $\mathrm{RH}$ or $\kappa$, which would cause the correction itself to vary. These new results therefore do not represent the real ratios at Chilbolton. Nevertheless, this exercise illustrates the importance of using dry aerosol samples for these measurements, however as mentioned in the previous paragraph, drying can also lead to the removal of volatile and semi-volatile compounds from the condensed phase. This is potentially a very important artefact in these measurements, which may lead to false agreement in reconciliation studies, and therefore requires further study.

The aerosol mixing state might also affect agreement, since the methods commonly used to derive hygroscopicity and $N_{\mathrm{CCN}}$ with the HTDMA and CCNc do not account for externally mixed aerosol, which can have different effects in the two instruments. A number of studies have considered this, using different methods to account for external mixing. Most of these (e.g. Rissler et al., 2004; Kammermann et al., 2010; Irwin et al., 2010) found that mixing state has no effect on measurement reconciliation, however Wex et al. (2010) found that it is important in obtaining agreement between between HTDMA and chemical composition derived hygroscopicity. For this study the mixing state was parameterised, using the HTDMA growth factor distribution, by the absolute value of the mean growth factor subtracted from the peak growth factor. Strong external mixing could be seen in the HTDMA measurements at Chilbolton and London (Summer and Winter), and the mixing state parameter ranged $0.12-0.20$. For measurements that showed a lesser degree of external mixing (i.e. a weaker secondary mode in the growth factor distribution; e.g. Borneo, Mace Head), the mixing state parameter ranged between 0.06 and 0.12 , and was less than 0.05 for measurements showing a largely internally mixed aerosol sample (e.g. Discovery cruise). Kammermann et al. (2010) accounted for external mixing in their reconciliation study by defining a critical growth factor at each dry diameter, above which particles activate at a given supersaturation. The fraction of particles above this growth factor is the activated fraction, thus providing an activation spectrum $\left(F_{\mathrm{A}}\left(S, D_{0}\right)\right)$ from which to calculate $D_{50}$ and hence $N_{\mathrm{CCN}}$ as described above. For the $\mathrm{CCNc}$, external mixing can be taken into account by integrating $N_{\mathrm{CCN}}\left(S, D_{0}\right)$ as a function of $D_{0}$ for each $S_{\text {set }}$. The ratios of the mean values of $N_{\mathrm{CCN}}$ derived from each method were calculated and compared to those shown in Fig. 3. No improvement was seen in reconciliation in any of the data sets, suggesting that mixing state does not affect hygroscopicity- $\mathrm{CCN}$ reconciliation, even when the degree of external mixing is high.

As already mentioned, there is a tendency in some of the data sets shown in Fig. 3 for the ratios to increase with decreasing supersaturation. A similar trend has also been observed in other studies (e.g. Kammermann et al., 2010; Fors et al., 2011), and has been explained as resulting from greater uncertainties in the instrument at lower supersaturations. The threshold diameter at these supersaturations is higher up in the tail of the particle number size distribution, and so predictions are more sensitive to the counting statistics in the size distribution. While this can explain the wide variation in the measurements (shown as large error bars) that can be seen here, it would not account for the bias (i.e. that $N_{\mathrm{CCN}(\mathrm{GF})}$ should be consistently less than $\left.N_{\mathrm{CCN}\left(D_{50}\right)}\right)$. A bias at low supersaturations due to uncertainties in the determination of the supersaturation would be eliminated by the calibration method applied to these data sets, and so would not explain it. Therefore, it is not clear what causes the larger bias at low supersaturations.

This trend is not observed in the data sets that show the poorest agreement (Discovery cruise, Hornisgrinde and Borneo), and it is noted that all these measurements were conducted with the same HTDMA (HTDMA1). However the measurements in Amazonia also employed HTDMA1 and these show relatively good reconciliation, plus the trend of higher ratios at lower supersaturations. The two HTDMAs were operated side by side, sampling ambient air in Manchester, UK, along with a CCNc, in order to compare reconciliation results. The derived $N_{\mathrm{CCN}}$ and $\kappa$ ratios are shown in Fig. S2. Better agreement is seen using HTDMA2, but importantly, both exhibit the trend of increased ratios at lower supersaturations that is seen in other data sets in Fig. 3. This information shows that differences between campaigns in the relationship between ratios of $N_{\mathrm{CCN}}$ or $\kappa$ and supersaturation cannot be attributed to different instruments. A detailed analysis of differences between HTDMA systems is provided by Duplissy et al. (2009) and Massling et al. (2011).

The wide range of locations from which the studies presented here derive make it possible to explore whether different environments (characterised by different aerosol populations) result in different degrees of reconciliation in water uptake measurements. No common patterns could be seen in Fig. 3 for measurements from similar environments, distinct from others, so there appears to be no such dependency.

For each data set, $N_{\mathrm{CCN}}$ was also calculated from both the HTDMA and CCNc data using campaign averages of either $\kappa$ (or $D_{50}$ in the case of the $\mathrm{CCNc}$ ) or size distribution. The results are shown in the Supplement as box plots of $N_{\mathrm{CCN}}$ as a function of supersaturation for each method. In most of the data sets, averaging $\kappa$ does not lead to a significant change in mean $N_{\mathrm{CCN}}(S)$ from either instrument, whereas $N_{\mathrm{CCN}}(S)$ derived using the mean size distribution shows a much reduced variability. Taken in isolation, the data from a single instrument may imply that $N_{\mathrm{CCN}}$ is rather insensitive to 
$\kappa$, and hence chemical composition and that, unsurprisingly, size distribution is more important for predicting $N_{\mathrm{CCN}}$, in agreement with previous studies (e.g. Dusek et al., 2006; Jurányi et al., 2010). However, that $N_{\mathrm{CCN}}$ derived from different instruments frequently differs markedly indicates a strong requirement to understand the processes leading to the discrepancies and thereafter to define a protocol for reliable $N_{\text {CCN }}$ quantification in line with our most informed understanding of the physical processes involved in their measurement.

\section{Conclusions}

This paper presents a meta-analysis of particle water uptake reconciliation studies from measurements taken at eight environmentally diverse locations, during three to six week field campaigns between 2007 to 2013. By examining such a range of data sets, it is possible to produce more general conclusions, particularly regarding instrumental discrepancies or different environments. Reconciliation between HTDMA and $\mathrm{CCNc}$ measurements was examined by comparing $N_{\mathrm{CCN}}$ and $\kappa$ as a function of supersaturation, derived from the threshold diameter seen with the $\mathrm{CCNc}$ and the mean growth factor measured by the HTDMA. Many of the data sets showed agreement within the variability of the measurements throughout the supersaturation range and some disagreed at all supersaturations. There did not appear to be any clear dependence of the degree of measurement reconciliation on whether the data set was collected in a marine, tropical, background continental or urban environment, and neither could differences between campaigns be attributed to the use of different instruments. There was generally poorer reconciliation at the lower supersaturations, likely resulting from greater relative uncertainties in the size distribution at the threshold diameters that are observed at these low supersaturations. Discrepancies at other supersaturations are attributed to differences in the chemical behaviour of vapours and/or particles in the different instruments. Aerosol mixing state did not appear to affect reconciliation, even when strong external mixing was observed. Calculating $N_{\mathrm{CCN}}$ from any one instrument using campaign averages of either $\kappa$ or size distribution would indicate relative insensitivity of $N_{\mathrm{CCN}}$ to the chemical composition with more of the variability in $N_{\mathrm{CCN}}$ arising from the size distribution. An improved understanding of the reasons for discrepancies in these reconciliation studies is needed, along with better knowledge of the processes underlying $\mathrm{CCN}$ measurements. This is vital to our ability to provide reliable quantification of $\mathrm{CCN}$ behaviour for use in aerosol-cloud interaction studies.

\section{The Supplement related to this article is available online at doi:10.5194/acp-14-11833-2014-supplement.}

Acknowledgements. The authors wish to thank Michael Flynn and Paul Williams for their assistance during the measurement campaigns. The authors would also like to express their thanks to Paulo Artaxo and colleagues for their assistance during the Amazonia measurements, and to Colin O'Dowd and colleagues for help with the measurements at Mace Head. We would like to acknowledge the following projects funded by the Natural Environment Research Council grants of the UK: COPS (Hornisgrinde; NE/E016200/1), RHaMBLe (Discovery cruise; NE/D006570/1), ACES (Borneo; NE/E011217/1), APPRAISE CLOUDS (Chilbolton; NE/E01125X/1), MC4 (Weybourne; NE/H008136/1), ClearfLo (London; NE/H003150/1), BUNIAACIC (Amazonia; NE/I030178/1), ACIDPRUF (NE/I020121/1). The Mace Head experiments were funded by the European Aerosols, Clouds and Trace gases Research InfraStructure (ACTRIS) Network.

Edited by: H. Su

\section{References}

Andreae, M. and Rosenfeld, D.: Aerosol-cloud interactions. Part 1. The nature and sources of cloud-active aerosols, Earth-Sci. Rev., 89, 13-41, doi:10.1016/j.earscirev.2008.03.001, 2008.

Artaxo, P., Rizzo, L. V., Brito, J. F., Barbosa, H. M. J., Arana, A., Sena, E. T., Cirino, G. G., Bastos, W., Martin, S. T., and Andreae, M. O.: Atmospheric aerosols in Amazonia and land use change: from natural biogenic to biomass burning conditions, Faraday Discuss., 165, 203-235, doi:10.1039/c3fd00052d, 2013.

Boucher, O., Randall, D., Artaxo, P., Bretherton, C., Feingold, G., Forster, P., Kerminen, V. M., Kondo, Y., Liao, H., Lohmann, U., Rasch, P., Satheesh, S. K., Sherwood, S., Stevens, B., and Zhang, X. Y.: Clouds and Aerosols, in: Climate Change 2013: The Physical Science Basis. Contribution of Working Group I to the Fifth Assessment Report of the Intergovernmental Panel on Climate Change, edited by: Stocker, T. F., Qin, D., Plattner, G.-K., Tignor, M., Allen, S. K., Boschung, J., Nauels, A., Xia, Y., Bex, V., and Midgley, P. M., Cambridge University Press, Cambridge, UK and New York, NY, USA, 2013.

Cubison, M., Coe, H., and Gysel, M.: A modified hygroscopic tandem DMA and a data retrieval method based on optimal estimation, J. Aerosol Sci., 36, 846-865, doi:10.1016/j.jaerosci.2004.11.009, 2005.

Dall'Osto, M., Monahan, C., Greaney, R., Beddows, D. C. S., Harrison, R. M., Ceburnis, D., and O'Dowd, C. D.: A statistical analysis of North East Atlantic (submicron) aerosol size distributions, Atmos. Chem. Phys., 11, 12567-12578, doi:10.5194/acp11-12567-2011, 2011.

Duplissy, J., Gysel, M., Sjogren, S., Meyer, N., Good, N., Kammermann, L., Michaud, V., Weigel, R., Martins dos Santos, S., Gruening, C., Villani, P., Laj, P., Sellegri, K., Metzger, A., McFiggans, G. B., Wehrle, G., Richter, R., Dommen, J., Ristovski, Z., Baltensperger, U., and Weingartner, E.: Intercomparison study of six HTDMAs: results and recommendations, Atmos. Meas. Tech., 2, 363-378, doi:10.5194/amt-2-363-2009, 2009.

Dusek, U., Frank, G., Hildebrandt, L., Curtius, J., Schneider, J., Walter, S., Chand, D., Drewnick, F., Hings, S., Jung, D., Borrmann, S., and Andreae, M.: Size matters more than chemistry 
for cloud-nucleating ability of aerosol particles, Science, 312, 1375-1378, doi:10.1126/science.1125261, 2006.

Dusek, U., Frank, G. P., Massling, A., Zeromskiene, K., Iinuma, Y., Schmid, O., Helas, G., Hennig, T., Wiedensohler, A., and Andreae, M. O.: Water uptake by biomass burning aerosol at suband supersaturated conditions: closure studies and implications for the role of organics, Atmos. Chem. Phys., 11, 9519-9532, doi:10.5194/acp-11-9519-2011, 2011.

Fors, E. O., Swietlicki, E., Svenningsson, B., Kristensson, A., Frank, G. P., and Sporre, M.: Hygroscopic properties of the ambient aerosol in southern Sweden - a two year study, Atmos. Chem. Phys., 11, 8343-8361, doi:10.5194/acp-11-8343-2011, 2011.

Frosch, M., Zardini, A. A., Platt, S. M., Müller, L., Reinnig, M.C., Hoffmann, T., and Bilde, M.: Thermodynamic properties and cloud droplet activation of a series of oxo-acids, Atmos. Chem. Phys., 10, 5873-5890, doi:10.5194/acp-10-5873-2010, 2010.

Frosch, M., Prisle, N. L., Bilde, M., Varga, Z., and Kiss, G.: Joint effect of organic acids and inorganic salts on cloud droplet activation, Atmos. Chem. Phys., 11, 3895-3911, doi:10.5194/acp11-3895-2011, 2011.

Good, N.: Measuring the hygroscopic properties and cloud activation of atmospheric aerosols, Ph.D. thesis, University of Manchester, 2009.

Good, N., Coe, H., and McFiggans, G.: Instrumentational operation and analytical methodology for the reconciliation of aerosol water uptake under sub- and supersaturated conditions, Atmos. Meas. Tech., 3, 1241-1254, doi:10.5194/amt-3-1241-2010, 2010a.

Good, N., Topping, D. O., Allan, J. D., Flynn, M., Fuentes, E., Irwin, M., Williams, P. I., Coe, H., and McFiggans, G.: Consistency between parameterisations of aerosol hygroscopicity and CCN activity during the RHaMBLe discovery cruise, Atmos. Chem. Phys., 10, 3189-3203, doi:10.5194/acp-10-3189-2010, 2010b.

Gysel, M., McFiggans, G., and Coe, H.: Inversion of tandem differential mobility analyser (TDMA) measurements, J. Aerosol Sci., 40, 134-151, doi:10.1016/j.jaerosci.2008.07.013, 2009.

Irwin, M., Good, N., Crosier, J., Choularton, T. W., and McFiggans, G.: Reconciliation of measurements of hygroscopic growth and critical supersaturation of aerosol particles in central Germany, Atmos. Chem. Phys., 10, 11737-11752, doi:10.5194/acp10-11737-2010, 2010.

Irwin, M., Robinson, N., Allan, J. D., Coe, H., and McFiggans, G.: Size-resolved aerosol water uptake and cloud condensation nuclei measurements as measured above a Southeast Asian rainforest during OP3, Atmos. Chem. Phys., 11, 11157-11174, doi:10.5194/acp-11-11157-2011, 2011.

Jurányi, Z., Gysel, M., Weingartner, E., DeCarlo, P. F., Kammermann, L., and Baltensperger, U.: Measured and modelled cloud condensation nuclei number concentration at the high alpine site Jungfraujoch, Atmos. Chem. Phys., 10, 7891-7906, doi:10.5194/acp-10-7891-2010, 2010.

Jurányi, Z., Tritscher, T., Gysel, M., Laborde, M., Gomes, L., Roberts, G., Baltensperger, U., and Weingartner, E.: Hygroscopic mixing state of urban aerosol derived from size-resolved cloud condensation nuclei measurements during the MEGAPOLI campaign in Paris, Atmos. Chem. Phys., 13, 6431-6446, doi:10.5194/acp-13-6431-2013, 2013.
Liu, D., Allan, J., Whitehead, J., Young, D., Flynn, M., Coe, H., McFiggans, G., Fleming, Z. L., and Bandy, B.: Ambient black carbon particle hygroscopic properties controlled by mixing state and composition, Atmos. Chem. Phys., 13, 2015-2029, doi:10.5194/acp-13-2015-2013, 2013.

Kammermann, L., Gysel, M., Weingartner, E., Herich, H., Cziczo, D. J., Holst, T., Svenningsson, B., Arneth, A., and Baltensperger, U.: Subarctic atmospheric aerosol composition: 3. Measured and modeled properties of cloud condensation nuclei, J. Geophys. Res.-Atmos., 115, D04202, doi:10.1029/2009JD012447, 2010.

Kokkola, H., Sorjamaa, R., Peräniemi, A., Raatikainen, T., and Laaksonen, A.: Cloud formation of particles containing humic-like substances, Geophys. Res. Lett., 33, L10816, doi:10.1029/2006GL026107, 2006.

Kumar, P., Sokolik, I. N., and Nenes, A.: Parameterization of cloud droplet formation for global and regional models: including adsorption activation from insoluble CCN, Atmos. Chem. Phys., 9, 2517-2532, doi:10.5194/acp-9-2517-2009, 2009.

Li, Z., Williams, A., and Rood, M.: Influence of soluble surfactant properties on the activation of aerosol particles containing inorganic solute, J. Atmos. Sci., 55, 1859-1866, 1998.

Massling, A., Niedermeier, N., Hennig, T., Fors, E. O., Swietlicki, E., Ehn, M., Hämeri, K., Villani, P., Laj, P., Good, N., McFiggans, G., and Wiedensohler, A.: Results and recommendations from an intercomparison of six Hygroscopicity-TDMA systems, Atmos. Meas. Tech., 4, 485-497, doi:10.5194/amt-4-485-2011, 2011.

McFiggans, G., Artaxo, P., Baltensperger, U., Coe, H., Facchini, M. C., Feingold, G., Fuzzi, S., Gysel, M., Laaksonen, A., Lohmann, U., Mentel, T. F., Murphy, D. M., O’Dowd, C. D., Snider, J. R., and Weingartner, E.: The effect of physical and chemical aerosol properties on warm cloud droplet activation, Atmos. Chem. Phys., 6, 2593-2649, doi:10.5194/acp-6-2593-2006, 2006.

Petters, M. D. and Kreidenweis, S. M.: A single parameter representation of hygroscopic growth and cloud condensation nucleus activity, Atmos. Chem. Phys., 7, 1961-1971, doi:10.5194/acp-71961-2007, 2007.

Prisle, N. L., Asmi, A., Topping, D., Partanen, A.-I., Romakkaniemi, S., Dal Maso, M., Kulmala, M., Laaksonen, A., Lehtinen, K. E. J., McFiggans, G., and Kokkola, H.: Surfactant effects in global simulations of cloud droplet activation, Geophys. Res. Lett., 39, L05802, doi:10.1029/2011GL050467, 2012.

Rissler, J., Swietlicki, E., Zhou, J., Roberts, G., Andreae, M. O., Gatti, L. V., and Artaxo, P.: Physical properties of the submicrometer aerosol over the Amazon rain forest during the wetto-dry season transition - comparison of modeled and measured CCN concentrations, Atmos. Chem. Phys., 4, 2119-2143, doi:10.5194/acp-4-2119-2004, 2004.

Rissler, J., Svenningsson, B., Fors, E., Bilde, M., and Swietlicki, E.: An evaluation and comparison of cloud condensation nucleus activity models: Predicting particle critical saturation from growth at subsaturation, J. Geophys. Res., 115, D22208, doi:10.1029/2010JD014391, 2010.

Roberts, G. C. and Nenes, A.: A Continuous-Flow Streamwise Thermal-Gradient CCN Chamber for Atmospheric Measurements, Aerosol Sci. Tech., 39, 206-221, doi:10.1080/027868290913988, 2005.

Rodríguez, S., Van Dingenen, R., Putaud, J.-P., Dell'Acqua, A., Pey, J., Querol, X., Alastuey, A., Chenery, S., Ho, K.-F., Harrison, 
R., Tardivo, R., Scarnato, B., and Gemelli, V.: A study on the relationship between mass concentrations, chemistry and number size distribution of urban fine aerosols in Milan, Barcelona and London, Atmos. Chem. Phys., 7, 2217-2232, doi:10.5194/acp-72217-2007, 2007.

Romakkaniemi, S., Kokkola, H., Smith, J. N., Prisle, N. L., Schwier, A. N., McNeill, V. F., and Laaksonen, A.: Partitioning of semivolatile surface-active compounds between bulk, surface and gas phase, Geophys. Res. Lett., 38, L03807, doi:10.1029/2010GL046147, 2011.

Sorjamaa, R., Svenningsson, B., Raatikainen, T., Henning, S., Bilde, M., and Laaksonen, A.: The role of surfactants in Köhler theory reconsidered, Atmos. Chem. Phys., 4, 2107-2117, doi:10.5194/acp-4-2107-2004, 2004.

Spracklen, D. V., Carslaw, K. S., Kulmala, M., Kerminen, V.-M., Sihto, S.-L., Riipinen, I., Merikanto, J., Mann, G. W., Chipperfield, M. P., Wiedensohler, A., Birmili, W., and Lihavainen, $\mathrm{H}$.: Contribution of particle formation to global cloud condensation nuclei concentrations, Geophys. Res. Lett., 35, L06808, doi:10.1029/2007GL033038, 2008.

Stevens, B. and Feingold, G.: Untangling aerosol effects on clouds and precipitation in a buffered system, Nature, 461, 607-613, doi:10.1038/nature08281, 2009.

Suda, S. R. and Petters, M. D.: Accurate determination of aerosol activity coefficients at relative humidities up to 99\% using the hygroscopicity tandem differential mobility analyzer technique, Aerosol Sci. Tech., 47, 991-1000, doi:10.1080/02786826.2013.807906, 2013.

Swietlicki, E., Hansson, H.-C., Hämeri, K., Svenningsson, B., Massling, A., McFiggans, G., McMurry, P. H., Petäjä, T., Tunved, P., Gysel, M., Topping, D., Weingartner, E., Baltensperger, U., Rissler, J., Wiedensohler, A., and Kulmala, M.: Hygroscopic properties of submicrometer atmospheric aerosol particles measured with H-TDMA instruments in various environments - a review, Tellus B, 60, 432-469, doi:10.1111/j.16000889.2008.00350.x, 2008.

Topping, D.: An analytical solution to calculate bulk mole fractions for any number of components in aerosol droplets after considering partitioning to a surface layer, Geosci. Model Dev., 3, 635-642, doi:10.5194/gmd-3-635-2010, 2010.
Topping, D. O. and McFiggans, G.: Tight coupling of particle size, number and composition in atmospheric cloud droplet activation, Atmos. Chem. Phys., 12, 3253-3260, doi:10.5194/acp-12-32532012, 2012.

Topping, D. O., McFiggans, G. B., and Coe, H.: A curved multicomponent aerosol hygroscopicity model framework: Part 1 - Inorganic compounds, Atmos. Chem. Phys., 5, 1205-1222, doi:10.5194/acp-5-1205-2005, 2005.

Topping, D. O., McFiggans, G. B., Kiss, G., Varga, Z., Facchini, M. C., Decesari, S., and Mircea, M.: Surface tensions of multicomponent mixed inorganic/organic aqueous systems of atmospheric significance: measurements, model predictions and importance for cloud activation predictions, Atmos. Chem. Phys., 7, 2371-2398, doi:10.5194/acp-7-2371-2007, 2007.

Topping, D. O., Connolly, P., and McFiggans, G.: Cloud droplet number enhanced by co-condensation of organic vapours, Nature Geosci., 6, 443-446, doi:10.1038/ngeo1809, 2013.

Twomey, S.: The influence of pollution on the shortwave albedo of clouds, J. Atmos. Sci., 34, 1149-1152, 1977.

Van Dingenen, R., Raes, F., Putaud, J.-P., Baltensberger, U., Charron, A., Facchini, M.-C., Decesari, S., Fuzzi, S., Gehrig, R., Hansson, H.-C., Harrison, R. M., Hüglin, C., Jones, A. M., Laj, P., Lorbeer, G., Maenhaut, W., Palmgren, F., Querol, X., Rodriguez, S., Schnieder, J., ten Brink, H., Tunved, P., Tørseth, K., Wehner, B., Weingartner, E., Wiedensohler, A., and Wåhlin, P.: A European aerosol phenomenology - 1: physical characteristics of particulate matter at kerbside, urban, rural and background sites in Europe, Atmos. Environ., 38, 2561-2577, doi:10.1016/j.atmosenv.2004.01.040, 2004.

Wex, H., McFiggans, G., Henning, S., and Stratmann, F.: Influence of the external mixing state of atmospheric aerosol on derived CCN number concentrations, Geophys. Res. Lett., 37, L10805, doi:10.1029/2010GL043337, 2010.

Zhou, J., Swietlicki, E., Hansson, H. C., and Artaxo, P.: Submicrometer aerosol particle size distribution and hygroscopic growth measured in the Amazon rain forest during the wet season, J. Geophys. Res.-Atmos., 107, 8055, doi:10.1029/2000JD000203, 2002. 